\title{
TAHOVÉ VLASTNOSTI TMELŮ PŘI TMELENÍ MATERIÁLU NA BÁZI CEMENTU
}

\author{
TENSIONAL PROPERTIES OF SEALANTS IN CEMENT-BASED \\ MATERIAL SEALING
}

Adam Boháček ${ }^{*}, 1$, Michal Brandtner ${ }^{2}$

*bohacek.a@fce.vutbr.cz

${ }^{1,2}$ Vysoké učení technické v Brně, Fakulta stavební, Veveří 331/95, 60200 Brno

\begin{abstract}
Abstrakt
Článek se zabývá problematikou tmelení materiálů na bázi cementu a tahovými vlastnostmi tmelené spáry. Jako podkladní materiál byla zvolena cementová deska Aquapanel, která byla ošetřována primerem. Poté byly aplikovány dva tmely, a to jeden zástupce akrylových a jeden zástupce polyuretanových tmelů. Po vytvrzení byla vzniklé zkušební tělesa podrobeny zkoušce podle platné evropské normy ČSN EN ISO 8340, která definuje parametry zkušebního tělesa i následné zkušební postupy. Hodnocení zkoušky, které probíhalo vizuálně a měřením posuvným měřítkem, ukázalo, že ke tmelení Aquapanelu lze doporučit pouze polyuretanový tmel. Tento tmel po vystavení zkoušce, na rozdíl od tmelu akrylového, nevykazoval žádné vady, je tedy možné ho uvést jako vhodný ke tmelení cementové desky Aquapanel.
\end{abstract}

\section{Klíčová slova}

Tmel, zkušební těleso, soudržnost, přilnavost, zkouška

\begin{abstract}
The article deals with sealing of cement-based materials and tensile properties of the sealed joint. Aquapanel cement board was chosen as the base material, which was treated with a primer. Then two sealants were applied, one representative of acrylic and one of polyurethane sealants. After curing, the resulting test specimens were tested according to the valid European standard CSN EN ISO 8340, which defines the parameters of the test specimen and subsequent test procedures. The evaluation of the test, which took place visually and with a caliper measurement, showed that only polyurethane sealant could be recommended for sealing Aquapanel. This putty, unlike acrylic putty, did not show any defects after the test, so it can be stated as suitable for sealing Aquapanel cement board.
\end{abstract}

Key words

Sealant, test specimen, cohesion, adhesion, test

\section{1 ÚVOD DO PROBLEMATIKY}

Lidská společnost se problematikou spojování různých typů materiálů zabývá prakticky od nepaměti. Za celou tuto dobu došlo k obrovskému pokroku v řešení této problematiky, at' už na poli používaných materiálů, kde došlo k posunu od přírodních materiálů ke složitým chemickým sloučeninám, tak i na poli aplikace tmelů. K největšímu rozmachu tmelení pak došlo v posledních dvou desetiletí. [1]

V dnešní době se můžeme s tmelenými spoji setkat doslova na každém kroku. Jejich hlavním účelem je zabránit látkové výměně mezi konstrukčními materiály a vnějším prostředím. Dále také zajišt'ují izolaci, a to jak tepelnou, tak zvukovou a některé dokonce přispívají k lepší požární rezistivitě konstrukcí. [2] Nalézáme je prakticky ve všech částech stavebních konstrukcí, a to např́klad mezi prefabrikovanými betonovými prvky ve fasádách, kolem oken a dveří, ve spojení mezi podlahami a stěnami atd. [2,3]

Na výdrž tmelených spojů jsou samozřejmě kladeny vysoké nároky. I z tohoto důvodu je nutné vždy vybírat tmel, který je vhodný pro tmelení zvoleného podkladu a je odolný vůči všem působícím vnějším vlivům. Nejčastějším vlivem, který na tmelené spoje působí jsou negativní klimatické jevy. [3] I když ale spotřebitel 
v případě výběru tmelu, který má odolávat klimatickým vlivům dá na doporučení výrobce, nemusí vždy tmelený spoj těmto vlivům odolat. Doporučení výrobce totiž ne vždy odpovídají skutečnosti. I z tohoto důvodu se autor rozhodl pro testování tmelů po vystavení negativním klimatickým vlivům a jejich porovnání.

$\mathrm{Na}$ trhu se pohybuje mnoho výrobců tmelů s širokým sortimentem nabízených tmelů od použití pro tmelení např́klad sádrokartonových konstrukcí v interiéru až po specializované tmely pro tmelení velkoformátových obkladových dílců na fasádách budov. Proto je pro běžného spotřebitele velice obtížné rozhodování, jaký produkt a od jakého výrobce vybrat. Tento článek má za úkol alespoň částečně tento výběr usnadnit, a to v oblasti tmelení podkladů na bázi cementu, jejichž zástupcem je právě cementová deska Aquapanel, která je využívána $\mathrm{v}$ interiérech tak exteriérech.

\section{MATERIÁL}

Pro účely výzkumu tmelů jsou vybrány dva tmely s příslušnými primery a podkladní materiál.

Podkladní materiál je volen na základě jeho problémovosti tmelení. Z tohoto důvodů je zvolen podkladní materiály na bázi cementu. Konkrétně je zvolena jako podkladní materiál cementová deska Aquapanel. Problémovost tkví ve výskytu jemných prachových částic na povrchu materiálu, které narušují soudržnost a prrilnavost tmelu k povrchu. Tento problém je z části eliminován použitím základního nátěru tzv. primeru, který je nanesen na podkladní materiál.

Tmely jsou následně vybrány na základě průzkumu trhu. A to především na základě jejich dostupnosti pro koncového zákazníka ale také na základě jejich pořizovací ceny. Nedílnou součástí na základě, které jsou tmely taktéž vybírány je také doporučení výrobce $\mathrm{k}$ tmelení vybraného podkladního materiálu. Na základě takto zjištěných skutečností jsou vybrány dva tmely, a to tmel akrylový a tmel polyuretanový od dvou významných výrobců dodávajících tmely na český trh.

Vybrané tmely (Tab. 1) a základní nátěry (Tab. 2) jsou dále specifikovány v níže uvedených tabulkách.

Tab. 1 Vlastnosti tmelů.

\begin{tabular}{ccc}
\hline Vlastnosti & Tmel $\mathbf{A}$ & Tmel $\mathbf{B}$ \\
\hline Hustota [g/cm3] & 1,3 & 1,71 \\
Pevnost v tahu [N/mm2] & 1,5 & 0,4 \\
Konzistence & Tixotropní pasta & Tixotropní pasta \\
Elastický modul pružnosti [N/mm2] & 0,6 & 0,4 \\
Tvrdost dle Shore $\mathbf{A}$ & 37 & 30 \\
\hline
\end{tabular}

Tab. 2 Vlastnosti primerů.

\begin{tabular}{ccc}
\hline Vlastnosti & Tmel A & Tmel B \\
\hline Hustota $[\mathbf{g} / \mathbf{c m} 3]$ & 1,0 & 1,01 \\
Konzistence & Tekutina & Nízkovizkózní kapalina \\
Obsah sušiny & 34 & - \\
\hline
\end{tabular}

\section{METODIKA}

Metodika použitá pro tento výzkum tmelů vychází z platné evropské normy ČSN EN ISO 8340. Tato norma jasně definuje parametry zkušebního tělesa a také samotný průběh zkoušky. Jediné, co není touto normou definováno je testovací zařízení, které bylo navrženo v předchozím výzkumu.

Zkušební těleso se skládá ze dvou podkladních destiček o půdorysném rozměru $25 \times 50 \mathrm{~mm}$ a tloušt'ce 12,5 mm. Dále se skládá ze dvou dřevěných rozpěrek o půdorysných rozměrech $12 \times 12$ mm a výšce $50 \mathrm{~mm}$. Rozpěrky a podkladní destičky spolu ohraničují prostor pro aplikaci tmelu o půdorysných rozměrech $12 \times 12 \mathrm{~mm}$ a výšce $50 \mathrm{~mm}$. Pro zkoušku je vyhotoveno pět zkušebních těles. Při jejich výrobě je třeba dbát pokynů výrobce tmelu včetně nanesení základního nátěru tzv. primeru na podkladní materiál. Dle technické normy je dále potřeba dodržen následující opatření: zkušební tělesa vyrábět při udržované teplotě $(23 \pm 2)^{\circ} \mathrm{C}$, vyloučit tvorbu 
vzduchových bublin, přitlačit těsnící tmel ke stykovým plochám podkladních těles a povrch tmelu uhladit do roviny pomocných těles a rozpěrek.

Před začátkem testování jsou zkušební tělesa uložena po dobu 28 dní při teplotě $(23 \pm 2){ }^{\circ} \mathrm{C}$ a relativní vlhkosti $(50 \pm 5)$ \% aby došlo ke správnému vyzrání tmelu. Následně musí zkušební tělesa projít tzv. kondicionováním. To znamená, uložením zkušebních těles dle předepsaného postupu. Postup uložení je následující:

- $\quad 3$ dny v sušárně při teplotě $(70 \pm 2)^{\circ} \mathrm{C}$

- 1 den v destilované vodě o teplotě $(23 \pm 2)^{\circ} \mathrm{C}$

- 2 dny v sušárně při teplotě $(70 \pm 2){ }^{\circ} \mathrm{C}$

- 1 den v destilované vodě o teplotě $(23 \pm 2)^{\circ} \mathrm{C}$

Tento postup je třikrát opakován.

Tato zkouška se provádí při teplotě $(23 \pm 2){ }^{\circ} \mathrm{C}$ a teplotě $(-20 \pm 2){ }^{\circ} \mathrm{C}$. Jak již bylo zmíněno výše technická norma popisuje průběh samotné zkoušky, který je následující. Nejprve jsou odstraněny dřevěné rozpěrky a zkušební těleso je vloženo do zkušebního zařízení, kde je protahováno při teplotě $(23 \pm 2){ }^{\circ} \mathrm{C}$ rychlostí $(5,5 \pm 0,7) \mathrm{mm} /$ minutu o $25 \%$ hodnoty původní délky. Protažení je v upínacích čelistech zkušebního zařízení při teplotě $(23 \pm 2){ }^{\circ} \mathrm{C}$ udržováno po dobu 24 hodin. Po uplynutí stanovené doby se zjišt'ují případně vzniklé poruchy přilnavosti a soudržnosti, které se měří vhodným měřícím zařízením s přesností čtení $0,5 \mathrm{~mm}$.

Zkouška při teplotě $(-20 \pm 2)^{\circ} \mathrm{C}$ probíhá obdobně jako při teplotě $(23 \pm 2)^{\circ} \mathrm{C}$. Zkušební tělesa se před samotným zkoušením uloží nejméně na 4 hodiny při teplotě $(-20 \pm 2)^{\circ} \mathrm{C}$. Poté jsou při teplotě $(-20 \pm 2)^{\circ} \mathrm{C}$ rychlostí $(5,5 \pm 0,7) \mathrm{mm} /$ minutu protahovány ve zkušebním zařízení o $25 \%$ hodnoty původní délky. Protažení je udržováno při teplotě $(-20 \pm 2)^{\circ} \mathrm{C}$ po dobu 24 hodin. Př́ípadně vzniklé poruchy přilnavosti a soudržnosti se zjišt’ují a měří vhodným měřícím zařízením s přesností čtení $0,5 \mathrm{~mm}$ až po vyndání zkušebních těles $\mathrm{z}$ chladící komory a jejich úplném rozmrznutí.

\section{VÝSLEDKY}

Pro každý vybraný tmel je podrobeno testování pět zkušebních těles. Hodnocení výsledků zkoušky probíhá vizuální kontrolou zkušebních těles a př́ípadně vzniklé vady soudržnosti a přilnavosti jsou přeměřeny posuvným měŕítkem. Výsledky jsou zaznamenány a popsány $\mathrm{v}$ tabulce Tab. 4. V tabulce je popsán způsob porušení zkušebních těles a pro větší přesnost při hodnocení výsledků je pak zapsána i délka porušení tmeleného spoje.

Zkušební tělesa, u kterých nevznikla žádná porucha tmeleného spoje jsou hodnoceny jako Vydržel. Tyto zkušební tělesa jsou ve výsledkové tabulce označeny slovem žádné. Naopak zkušební tělesa, u kterých došlo k narušení tmeleného spoje mají ve výsledkové tabulce popsánu vadu tmeleného spoje, která vznikla. U tohoto zkušebního souboru vznikla pouze jedna vada, a to trhlina mimo oblast styku tmelu a podkladního materiálu $\mathrm{v}$ tabulce označené zjednodušeně pouze jako vznik trhliny. Tato délka trhliny je zapsána v tabulce výsledků. Ve výsledkové tabulce Tab. 4 je u tmele $\mathrm{B}$ výsledek zkoušky proškrtnut, a to $\mathrm{z}$ toho důvodu, že došlo k úplnému odtržení tmelu od podkladního materiálu již při protahování zkušebních těles ve zkušebním zařízení.

Pod tabulkami výsledků je možno vidět fotografie zkušebních těles po zkoušení. Na Obr. 1 a Obr. 2 jsou zkušební tělesa zkoušená při teplotě $(23 \pm 2)^{\circ} \mathrm{C}$ a na Obr. 3 a Obr. 4 jsou zkušební tělesa zkoušená při teplotě $(-20 \pm 2){ }^{\circ} \mathrm{C}$.

Tab. 3 Zkouška dle ČSN EN ISO 8340 při teplotě $(23 \pm 2){ }^{\circ} \mathrm{C}$.

\begin{tabular}{cccccc}
\hline Typ tmelu & Zkušební & Zkušební & Zkušební & Zkušební & Zkušební \\
& těleso & těleso & těleso & těleso & těleso \\
& č. 1 & č. 2 & č. 3 & č.4 & ć. 5 \\
\hline Tmel A (Polyuretanový tmel) & Žádné & Žádné & Žádné & Žádné & Žádné \\
Tmel B (Akrylový tmel) & Vznik trhliny / Vznik trhliny / Vznik trhliny / Vznik trhliny / Vznik trhliny / & & $49 \mathrm{~mm}$ & $45 \mathrm{~mm}$ \\
\hline
\end{tabular}

Tab. 4 Zkouška dle ČSN EN ISO 8340 při teplotě $(-20 \pm 2)^{\circ} \mathrm{C}$.

\begin{tabular}{cccccc}
\hline Typ tmelu & Zkušební & Zkušební & Zkušební & Zkušební & Zkušební \\
& těleso & těleso & těleso & těleso & těleso \\
č. 1 & č. 2 & č. 3 & č. 4 & Ž 5 \\
\hline Tmel A (Polyuretanový tmel) & Žádné & Žádné & Žádné & Žádné & Žádné
\end{tabular}




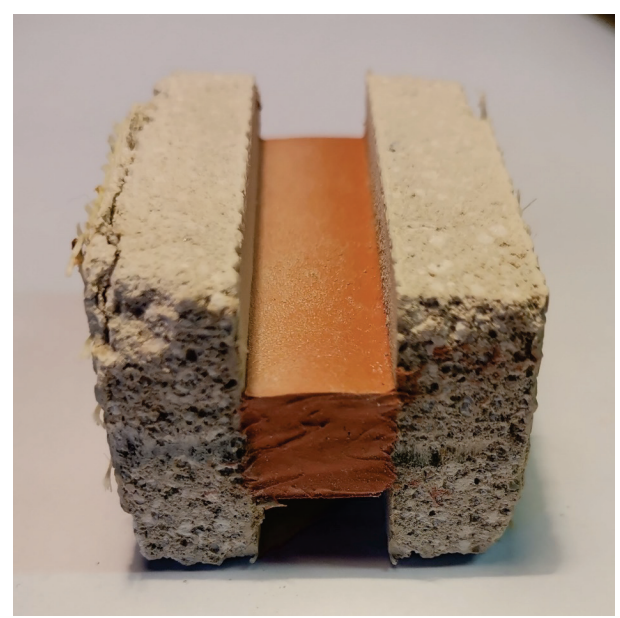

Obr. 1 Tmel A, zkušební těleso 2.

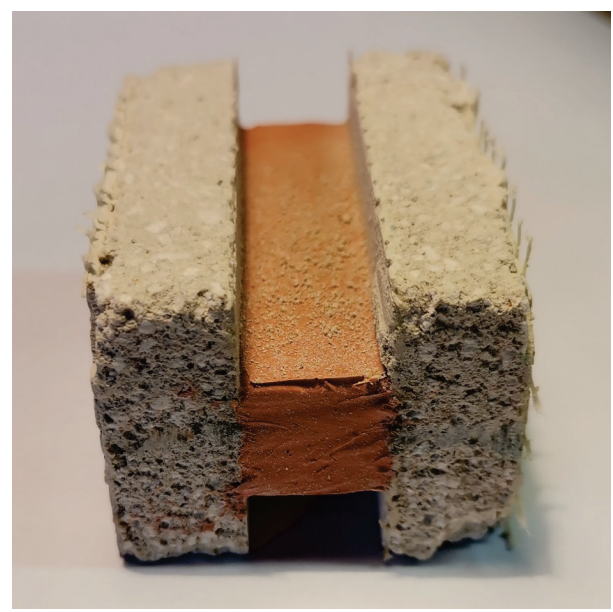

Obr. 3 Tmel A, zkušební těleso 1.

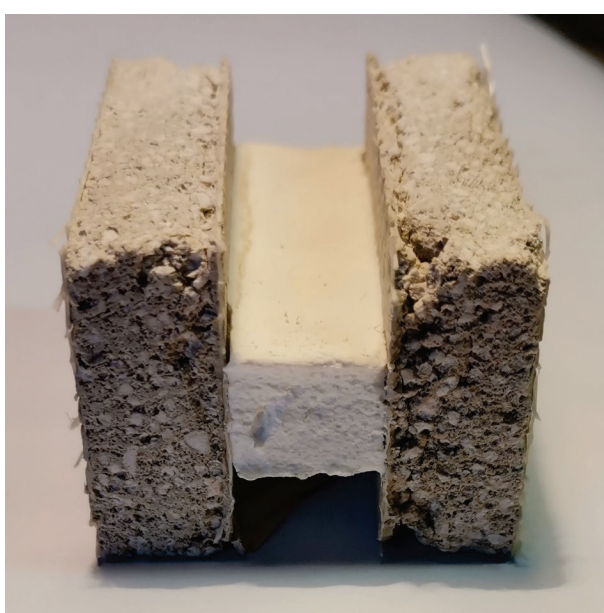

Obr. 2 Tmel B, Zkušební těleso 5.

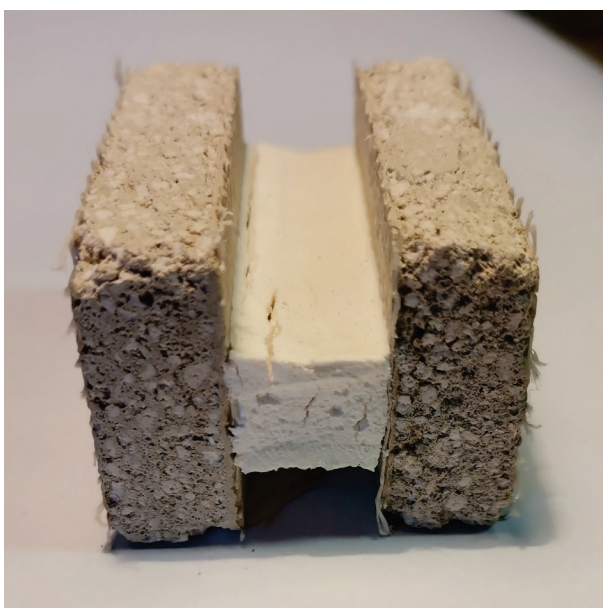

Obr. 4 Tmel B, zkušební těleso 3.

\section{ANALÝZA VÝSLEDKŮ}

Z výsledkových tabulek jasně vyplývá, že tmel A zkoušený jak při teplotě $(23 \pm 2){ }^{\circ} \mathrm{C}$ tak při teplotě $(-22 \pm 2){ }^{\circ} \mathrm{C}$ vyhověl podmínkám zkoušky při kladné i záporné hodnotě tepltoy a nedošlo u něj k porušení soudržnosti a přilnavosti tmeleného spoje tedy nebyl narušen styk mezi tmelem a podkladním materiálem. Nedošlo ani $\mathrm{k}$ jakémukoliv defektu tmeleného spoje v prostoru tmelu samotného.

$\mathrm{U}$ tmelu $\mathrm{B}$, jsou výsledky o mnoho horší. U zkoušky při teplotě $(23 \pm 2){ }^{\circ} \mathrm{C}$ došlo ke vzniku trhliny v různých délkách u všech pěti testovacích těles. Vznik těchto trhlin nikoliv na styku tmele a podkladního materiálu ale př́mo v prostoru aplikovaného tmele je přisuzován malé elasticitě tmele po je vyzrání. U zkoušky při teplotě $(-22 \pm 2)^{\circ} \mathrm{C}$ nebylo možné tmel $\mathrm{B}$ vůbec hodnotit, protože došlo k úplnému odtržení tmelu od podkladního materiálu již při protahování zkušebních těles ve zkušebním zařízení. 


\section{ZÁVĚR}

I přes to, že pro tento výzkum tmelů byly vybrány dva tmely, které jsou výrobci doporučeny k tmelení vybraného podkladního materiálu, tak i přesto jeden z vybraných tmelů konkrétně akrylový tmel, jak je patrné z výsledkových tabulek nevyhověl. Oproti tomu polyuretanový tmel nevykazoval žádné vady a je tedy možno ho doporučit ke tmelení vybraného podkladního materiálu na bázi cementu, kterým je cementová deska Aquapanel.

\section{Poděkování}

Př́íspěvek vznikl za podpory juniorského specifického výzkumu Fakulty stavební Vysokého učení technického v Brně vedeného pod označením FAST-J-21-7288.

\section{Použité zdroje}

[1] Klosowski, J., Wolf, A. T. Sealants in construction. 2nd edition. Boca Raton: Taylorand Francis Group, 2016. ISBN 978-1-4200-1785-4.

[2] Petrie, E. M. Handbook of adhesives and sealants. New York: McGraw-Hill company, 2009. ISBN 0-07049888-1.

[3] Lal Mittal, K., Pizzi, A. Handbook of sealant technology. Boca Raton: Taylor and Francis Group, 2009. ISBN 978-0-8493-9162-0.

[4] Chew, M. Z. L., Zhou, X.,Tan, S. T., On-site weathering of sealants under tropical conditions, Construction and Building Materials, Vol. 18, Issue 4, 2004, pp. 287-293.

[5] Stögbauer, H., Wolf, A. T. The influence of heat ageing on one-part construction silicone sealants, Construction and Buildings Materials, Vol. 5, Issue 1, 1991, pp. 27-32.

[6] Wolf, A. T. Movement capability of sealants. Construction and Building Materials. 1991, 5, s.127 - 134. DOI: 10.1016/0950-0618(91)90063-Q. ISSN 09500618.

[7] Šlanhof, J., Šimácková, M., Liška, P., Nečasová, B. Sealing possibilities of glass fibre reinforced concrete elements and fibre - Cement facade cladding panels (2014) Proceedings of an International Scientific Conference in Bratislava - Construction Technology and Management CTM 2014, pp. 447-455. Bratislava: Slovak University of Technology in Bratislava

[8] Šlanhof, J., Liška, P. and Nečasová, B. 2017. Evaluation of test methods for testing of sealants, Advances and Trends in Engineering Sciences and Technologies II - Proceedings of the 2nd International Conference on Engineering Sciences and Technologies, ESaT 2016 2017, pp. 643-648, ISBN: 978131539382-7.

[9] ČSN EN ISO 8340 Stavební konstrukce - Těsnící hmoty - Tmely - Stanovení tahových vlastností při udržovaném protažení. Praha: Český normalizační institut, 2006.

[10] Informace $\mathrm{z}$ https://www.knauf.cz/

[11] Informace $\mathrm{z}$ https://www.denbraven.cz/

[12] Informace $\mathrm{z}$ https://cze.sika.com 